\title{
BENTUK KOREOGRAFI REYOG KENDANG SANGGAR "SANGTAKASTA" KABUPATEN TULUNGAGUNG
}

\author{
Oleh: Yussi Ambar Sari
}

(Pembimbing Tugas Akhir: Prof. Dr. AM. Hermien Kusmayati, S.S.T., SU dan Dra. Winarsi Lies Apriani, M. Hum)

Jurusan Tari, Fakultas Seni Pertunjukan, Institut Seni Indonesia Yogyakarta. Email: yussikencus28@yahoo.com

\begin{abstract}
RINGKASAN
Reyog Kendang merupakan tarian khas Tulungagung, yang tergolong tarian kelompok dengan jumlah penari 6 sesuai jumlah properti kendang. Adapun kendang sebagai properti utamanya, terdiri dari: Kendang 1, Kendang 2, Trinting, Imbal 1, Imbal 2, dan Keplak. Tarian ini bisa ditarikan oleh laki-laki ataupun perempuan. Tarian ini menggambarkan arak-arakan prajuri Kediri ketika mengiringi pengantin Ratu Kilisuci ke Gunung Kelud. Inti dari beberapa cerita tersebut tentang lamaran seorang Putri cantik yang bernama Klilisuci. Salah satu sanggar yang melestarikan tarian ini adalah Sanggar Sangtakasta, pimpinan Endin Didik Handoko, yang diresmikan tanggal 13 April 2013.

Penelitian ini menganalisis bentuk Koreografi Reyog Kendang Sanggar Sangtakasta di Tulungagung. Untuk itu digunakan pendekatan koreografi yang i analisisi koreografi dengan analisis bentuk gerak, teknik gerak, isi gerak, aspek ruang, aspek waktu, aspek tenaga, dan gaya gerak.

Hasil analisis menunjukkan bahwa Sanggar Sangtakasta memiliki variasi dalam bentuk gerak, rias dan tata iringan. Jumlah 8 penari yang terdiri dari

4 penari perempuan dan 4 penari laki-laki, membuat koreografi dalam wujud gerak, desain lantai, dan permainan level tarian ini semakin menarik. Rias yang digunakan penari perempuan menggunakan rias korektif, sedangkan penari laki- laki menggunakan rias karakter. Instrumen selain kendang dalam tarian ini yaitu saron demung, kenthongan, calung, gitar, siter, tamborin, drum, gong, kenong, suling, rinding, angklung, dan bass.
\end{abstract}

Kata kunci: Reyog Kendang, Bentuk Koreografi, Tarian. 


\section{ABSTRACT}

Reyog Kendang is a typical Tulungagung dance, which belongs to group dance with 6 dancer in accordance with the number of kendang properties or can be more. This dance uses kendang as its main property, drum numbering 6 of them Kendang 1, Kendang 2, Trinting, Imbal 1, Imbal 2, and Keplak. This dance can be danced by men or women. The dance depicts the parade of the soldiers' warriors when accompanying the quin of the Kilisuci to the Mountain Kelud. The core of some of these stories about the application of a beautiful princess named Kilisuci. One of studio that preserves this dance is Studio Sangtakasta, head of Endin Didik Handoko, which was inaugurated on 13 April 2013. Sangtakasta is an acronym for dance studio and karawitan art of Tulungagung.

This study aims to reveal the form of Reyog Kendang Studio Sangtakasta in Tulungagung. In dissecting this dance using a choreographic dance text analysis by looking at aspects of motion shape analysis, motion technique analysis, motion content, space aspect, time aspect, energy aspect, and motion style. Dissects the choreographic forms using the Y. Sumandyo Hadi book entitled aspects of basic choreographic groups.

The result of the choreographic form indicate that the Sangtakasta Studio has variations in the form of motion, make up, and arrangement. A total of 8 dancers consisting of 4 famale dancers an 4 male dancers, making choreography in the form of motion, floor design, and dance level games are more interesting. The dresser used by female dancers using a corrective make up, while male dancers use a character dressing. Instruments other than drums in this dance is saron demung, kenthongan, calung, gitar, siter, tamborin, drum, gong, kenong, suling, rinding, angklung, and bass.

Key words: Reyog Kendang, Choreographic from, Dance.

\section{PENDAHULUAN}

Tari Reyog Kendang merupakan kesenian tradisional masyarakat Kabupaten Tulungagung. Tarian ini menggambarkan arak-arakan prajurit Kediri ketika mengiringi pengantin Ratu Kilisuci ke Gunung Kelud.
Pada suatu hari berangkatlah arak-arakan pengantin yang panjang dan megah menuju ke selatan, untuk menyaksikan dari dekat hasil pekerjaan Jathasura dan Lembusura dalam membuat sebuah sumur kembar sebagai permintaan Dewi Kilisuci. Sang Dewi beserta 


\section{JOGED}

ISSN: 1858-3989

rombongan melihat apakah pekerjaan Jathasura dan Lembusura sudah memenuhi persyaratan yang dikehendaki atau belum. Beberapa rombongan prajurit yang menyamar sebagai penari reyog sembari terus membunyikan gembluknya untuk mengiringi Sang Dewi menuju Gunung Kelud. Jathasura dan Lembusura telah memenuhi persyaratan dari Kilisuci, namun masih ada persyaratan lainya, yaitu harus membuktikan bahwa kedua sumur itu berbau wangi atau harum dan Badeg atau amis. Akhirnya Jathasura dan Lembusura harus mengambil air di dalam sumur yang dibuatnya. Jathasura masuk kedalam sumur yang berbau wangi, sedangkan Lembusura kedalam sumur yang badeg dan amis. Meninggalnya Jathasura dan Lembusura ditimbun ke dalam sumur oleh prajurit yang menyamar sebagai penari (Wawancara dengan Untung Mulyono, di rumahnya di Dusun Sorogenen pada tanggal 7 Februari 2017, diizinkan dikutip).

Istilah Reyog Kendang jika ditinjau dari pengertian masyarakat di daerah Kabupaten Tulungagung merupakan sebuah jenis pertunjukan tari yang menggunakan kendang sebagai properti yang sekaligus instrumen pokoknya. Reyog Kendang lebih cenderung pada sekumpulan penari yang memainkan alat musik kendhang atau gembluk. Kata kendang adalah sebutan populer saat ini meminjam nama alat musik kendang pada ansambel gamelan, yang sebenarnya nama asli adalah gembluk. Gembluk di samping bentuk alat tersebut jembluk (cembung atau gemuk) juga suara yang dihasilkan adalah "bluk" dalam timbre (warna suara) dari besar berurutan mengecil (enam warna suara). Pemain akan fokus memainkan kendhang sebagai instrumen utama dalam pertunjukannya yang mengatur tempo dan pola ritmis pada gerakan tarian. Kendang (gembluk) dalam reyog ini tidak seperti kendang dalam gamelan, kendang reyog bermembran satu (bagian depan) sedangan sisi belakang berlubang. Sebagai membran adalah kulit kambing yang telah dikeringkan, bukan kulit sapi karena terlalu tebal dan keras, hasil suaranya tidak sebaik kulit kambing.

Reyog Kendang tergolong tarian kelompok dengan jumlah penari 6 , sesuai jumlah kendhang dalam satu set (unit) ada 6 . Tarian ini bisa ditarikan oleh laki-laki ataupun perempuan. Gerak tari Reyog Kendang yang menonjol adalah langkah-langkah kaki yang serempak dalam berbagai variasi, misalnya dalam motif ngongak sumur yaitu gerakan kaki kanan melangkah meloncat ke depan (membungkuk), kemudian ke belakang (tegap) dengan posisi kaki kiri diangkat. Adakalanya badan membungkuk bagaikan menahan berat beban dalam perjalanan yang jauh, seperti motif yang diberi nama menthokan. 
Semua adegan itu dilakukan melalui simbolsimbol gerak tari yang ekspresif dan mempesona, diwujudkan dengan menggunakan langkah-langkah kaki yang serempak dalam berbagai variasi. Langkah kaki tersebut didukung atau dipertajam dengan gerakan-gerakan lambung, pundak, leher dan kepala, disertai mimik yang serius, sedang kedua tangan yang kiri memegang bibir kendang yang bermembran, tangan kanan sebagai pemukul kendang. Posisi kendang diikat (digendhong) dengan kain gendhong dari pundak sebelah kanan menyilang ke kiri bawah sampai lambung kiri.

Motif yang ada dalam Reyog Kendang di antaranya baris, sundhangan, andhul, menthogan, gejoh bumi, ngongak sumur, midak kecik, ling-lingan, dan kejang (Pemerintah Daerah Kabupaten Tingkat II Tulungagung, 1996, Reyog Tulungagung Dalam Rangka Pendokumentasian, Pendiskripsian dan Pembuatan Pedoman Tari Khas Tulungagung, Tulungagung, 10). Motif dalam tarian ini bisa dilakukan berulangulang tergantung penata tari atau koreografernya. Gerak dalam tarian ini sangat variatif, oleh sebab itu hampir setiap perkumpulan atau sanggar selalu memiliki variasi gerak, dan menciptakan ragam gerak yang khas. Kendang 1 (dhodhog) sebagai pamurba atau yang memberi perintah untuk berganti gerak dan irama adalah sebagai pemimpin tarian ini, dengan variasi pola lantai yang digunakan seperti melingkar, memutar, berbanjar, zig-zag, berpasangan, dan variasi pola lantai lainnya. Kostum yang dikenakan diantaranya udheng, iker-iker, sumping, kace, srempang, ter, baju, celana, jarik, sabuk motif cinde, sabuk, bara, sampur, keris, deker, gongseng, kaos kaki, dan kain gendhong.

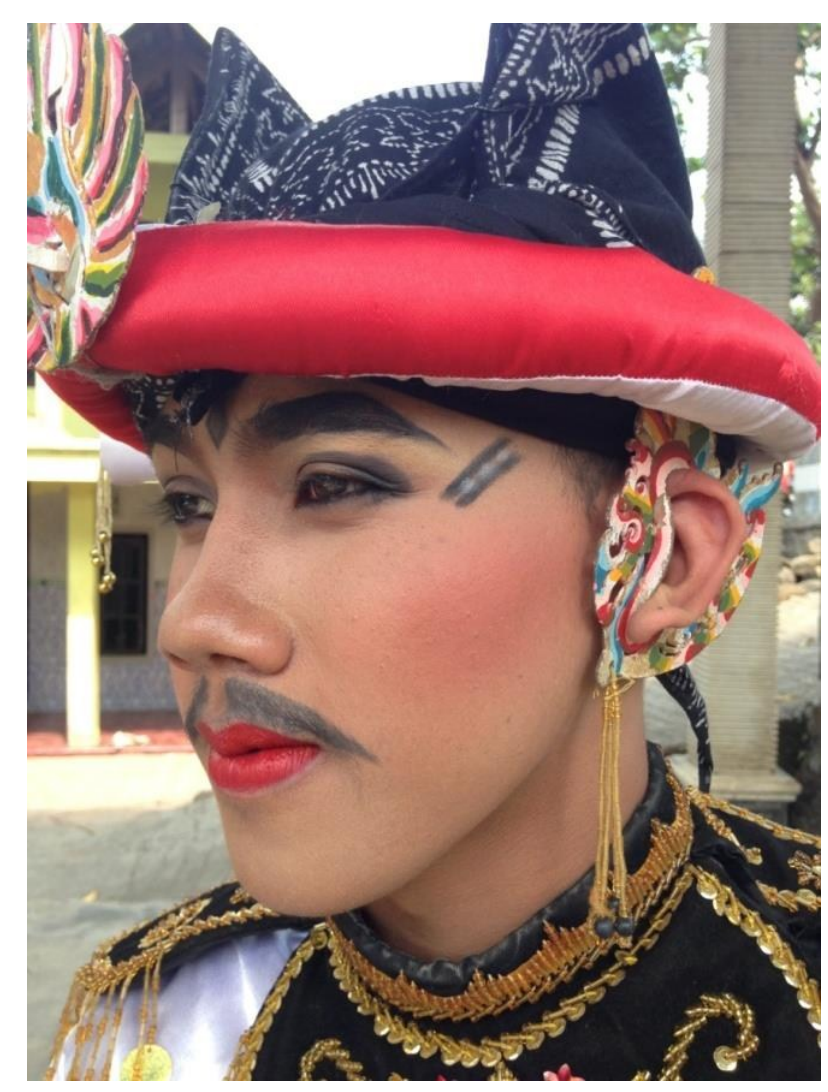

(Gambar 1. Rias karakter penari laki-laki dan kostum bagian kepala. 2013. Sanggar Sangtakasta. Dok: Yussi Ambar Sari). 
JOGED

ISSN: $1858-3989$

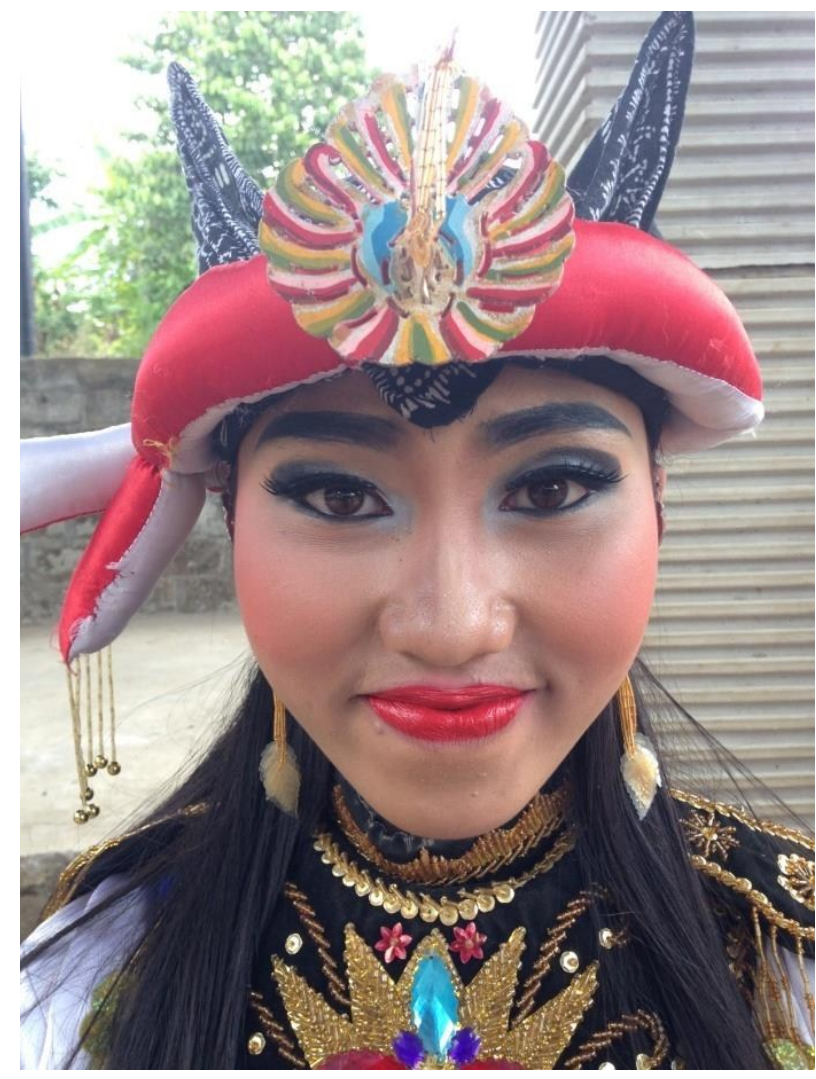

(Gambar 2. Rias korektif penari perempuan dan kostum bagian kepala. 2013. Sanggar Sangtakasta. Dok: Yussi Ambar Sari).

Tempat pementasan untuk tarian ini ditarikan di lapangan, panggung, gedung, bahkan di jalan raya (arak-arakan). Reyog Kendang yang dulunya sebagai sarana ritual, pada saat ini telah berubah fungsi sebagai sarana hiburan, sarana komunikasi, media ekspresi, dan media komersial untuk mencari nafkah. Sampai sekarang Reyog Kendang juga sering ditampilkan dalam acara Hari Jadi Kota Tulungagung, Festival, Upacara 17 Agustus. Tahun 2015 lalu Reyog Kendang dipertunjukkan dalam pawai-pawai besar untuk memecahkan Rekor Muri pada tanggal 13 November 2015 dengan jumlah sebanyak 2.400 penari Reyog Kendang.

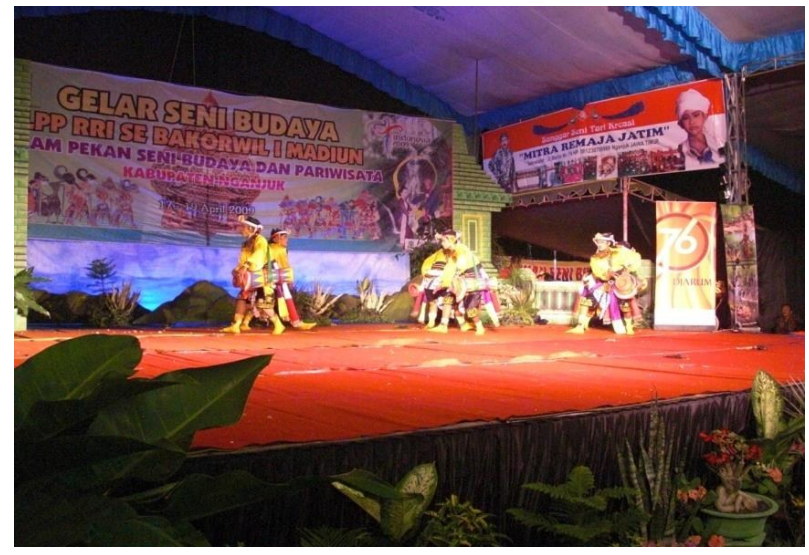

(Gambar 3. Pentas Gelar Seni Budaya oleh enam penari putra. 2009. Madiun Dok: Endin Didik)

Reyog Kendang di Tulungagung dalam dasa warsa terakhir tidak terlepas dari perhatian pemerintah dalam hal ini Dinas Pendidikan, pendidikan dari SD, SMP dan SMA serta Dinas Kebudayaan dan Olahraga masyarakat desa maupun sanggar-sanggar seni yang ada di Tulungagung. Terlebih kesenian Reyog Kendang merupakan icon atau yang paling diunggulkan disamping kesenian lainnya yang ada di Tulungagung.

Reyog Kendang Sanggar Sangtakasta adalah salah satu Sanggar yang ikut berperan dan berpartisipasi aktif di Desa Tugu, Kecamatan Sendang, Kabupaten Tulungagung, pimpinan Endin Didik Handoko. Sangtakasta adalah singkatan Sanggar Tari dan Seni Karawitan Sendang Tulungagung. Sanggar ini mulai diresmikan pada tanggal 13 April 2013. Dalam penelitian ini peneliti memilih pementasan Reyog Kendang Sanggar Sangtakasta dalam rangka Festival Gamelan Nusantara tahun 2017 yang bertempat di Desa Njoho, Kecamatan 
Kalidawir, Kabupaten Tulungagung. Acara tersebut berlangsung pada malam hari, dan diselenggarakan tanggal 26 Maret 2017.

\section{Pendekatan yang dilakukan oleh} peneliti yaitu pendekatan koreografi, secara sistematik dibedah dengan melihat analisis bentuk gerak, analisis teknik gerak, analisis gaya gerak, analisis jumlah penari, analisis jumlah penari, analisis jenis kelamin dan postur tubuh, analisis struktur keruangan, analisis struktur waktu, analisis struktur dramatik, analisis tata teknik pentas yang mencakup tata cahaya dan tata rias busana. Pendekatan koreografi menggunakan buku Y. Sumandiyo Hadi dalam bukunya Aspek-Aspek Dasar Koreografi Kelompok. Alasan peneliti menggunakan pendekatan bentuk koreografi untuk membedah permasalahan koreografi tari Reyog Kendang Sanggar Sangtakasta.

\section{PEMBAHASAN}

A. Bentuk Koreografi Reyog Kendang Sanggar Sangtakasta Ditinjau Dalam

Aspek Bentuk, Teknik, Isi.

1.Aspek Bentuk Tari

Sajian Tari Reyog Kendang Sanggar Sangtakasta dilihat dari bentuknya meliputi keutuhan gerak, variasi pola lantai, pengulangan gerak, serta transisi motif, dari motif satu ke motif lainnya. Gerak dalam tarian ini menggambarkan beberapa gerak yang dilakukan oleh prajurit Dewi Kilisuci, dan divariasikan menjadi lebih ritmis dan dinamis. Dinamika tidak hanya terdapat pada bentuk koreografinya tetapi juga pada iringannya. Untuk mempermudah suatu gambaran dengan jelas dalam penyajiannya dan sistematis bentuk garapan secara garis besar, maka dikemukakan menjadi tiga bagian yaitu bagian awal, tengah, dan akhir. Dalam penelitian ini penulis memilih Reyog Kendang Sanggar Sangtakasta dalam rangka Festival Gamelan Nusantara tahun 2017 yang bertempat di Desa Njoho, Kecamatan Kalidawir, Kabupaten Tulungagung. Penari dalam acara Festival tersebut berjumlah delapan penari, yang terdiri dari empat penari laki-laki dan empat penari perempuan yang masih remaja.

Bagian Awal, tarian menggambarkan arak-arakan prajurit ketika mengiringi Dewi Kilisuci menyaksikan pekerjaan Jathasura. Bagian Tengah, Bagian tengah menggambarkan ketika Jathasura masuk ke dalam sumur dan dilempari batu oleh para penari. Bagian Akhir, bagian akhir menunjukkan kegembiraan prajurit dan Dewi Kilisuci kembali menuju kerajaan Kediri. Aspek Teknik Tari

Teknik instrument dibagi menjadi:

a. Kepala

Gerak dasar kepala yang terdapat dalam tarian ini adalah tolehan, yaitu sikap kepala menoleh ke arah kanan dan kiri secara 


\section{JOGED}

ISSN: 1858-3989

bergantian setiap empat hitungan. Sikap kepala tolehan terdapat dalam motif sundhangan. Sikap berikutnya yaitu manggut-manggut, yaitu bagian dagu dan leher digerakkan maju mundur dengan tempo yang cepat. Gerak kepala manggutmanggut terdapat dalam motif menthokan dan midak kecik. Sikap kepala selanjutnya adalah Tangan

Sikap tangan dalam tarian ini di fokuskan pada properti yang digunakan, yaitu kendang. Tangan bagian kiri memegang kendang yang sudah diikat pada bagian kiri penari dengan menggunakan kain gendhong. Tangan kanan memukul kendang, variasi tangan selain memukul kendang yaitu ngeruji, ngepel, dan ngukel. Sikap ngeruji terdapat dalam motif drum band, pengembangan tangan, dan gerak perang. Sikap ngukel dalam motif drum band, dan sikap ngepel dalam motif perangan dan pengembangan tangan.

b. Badan

Badan memiliki aturan-aturan tersendiri dalam melakukan motif, dalam tarian ini ada beberapa sikap badan di mana sikap badan tegak dada dibusungkan, mendhak mayuk, mendhak sambil badan membungkuk, dan perut nglempet atau dikecilkan. Posisi badan memang harus selalu tegak dan selalu mendhak dalam menari. Hampir setiap motif dalam tari Reyog Kendang menggunakan sikap badan mendhak, sikap badan seperti ini akan memberikan kesan kokoh pada gerak yang dilakukan. Misalnya pada motif sundhangan, katika kaki dibuka lebar dan ditambah mendhak mayuk. Apabila sikap badan tidak diterapkan maka motif ini akan terlihat lemah.

\section{c. Kaki}

Kaki menjadi bagian penumpu titik berat badan dan banyak mengeluarkan tenaga paling besar, ditambah dengan sikap jari kaki nylekenthing. Selain sebagai penumpu kaki harus memiliki kekuatan, dan dapat dilihat kokoh gerak yang ditampilkan melalui kekuatan kaki yang disiplin. Hampir semua gerakan kaki dalam tarian ini disertai dengan sikap nylekenting, kecuali jika kaki sedang jinjit.

\section{Aspek Isi Tari}

Inti dalam tarian ini mengenai penggambaran prajurit yang mengiringi Dewi Kilisuci menuju gunung Kelud, ketika melihat hasil pekerjaan Jathasura antara lain membuatkan sumur di lereng gunung Kelud. Beberapa motif yang menggambarkan prajurit yang mengiringi Dewi Kilisuci adalah motif menthokan, dimana dalam motif tersebut digambarkan penari mendhak dengan posisi badan membungkuk bagaikan menahan beban ketika mengiringi Dewi Kilisuci. 
B. Bentuk Koreografi Reyog Kendang Sanggar Sangtakasta Ditinjau Dalam

Aspek Ruang, Waktu, dan Tenaga.

\section{Aspek Ruang}

Aspek ruang yang terdapat dalam Reyog Kendang Sanggar Sangtakasta digambarkan dengan arah hadap, level, dan pola lantai. Berikut dipaparkan bagian dari aspek ruang.

a. Arah Hadap

Arah hadap Reyog Kendang Sanggar Sangtakasta sangat beragam, bisa saling berhadap-hadapan antara penari, menghadap satu arah, dan mengahadap saling membelakangi. Pada salah satu motif gerak sangat terlihat perbedaan arah hadapnya, hal ini dimaksudkan supaya tari ini terlihat menarik. Misalnya pada bagian awal tarian dalam motif ling- lingan, empat penari putra berbaris dibelakang dua penari saling berhadap- hadapan, sedangkan yang empat penari perempuan berkumpul di depan membentuk lingkaran dengan menghadap satu arah ke depan.

b. Level

Level merupakan tinggi rendahnya badan dalam melakukan motif tari tersebut. Level terbagi menjadi tiga yaitu level rendah, sedang, dan tinggi. Tarian ini terdapat permainan level di antaranya pada bagian tengah tarian, di mana antara penari putra dan putri bergantian melakukan motif sundhangan dan midak kecik. Perbedaan level pada motif ini nampak sekali perbedaannya. Level medium adalah posisi penari berdiri sempurna atau normal yang memudahkan untuk bergerak kemana saja (Y.Sumandyo Hadi, 2014, Koreografi Bentuk-Teknik-Isi, Yogyakarta: Cipta Media, 18). Level rendah adalah posisi badan merendah karena kaki sebagai penyangga dalam posisi ditekuk atau mendhak (Y.Sumandyo Hadi, 2014, Koreografi Bentuk-Teknik-Isi, Yogyakarta: Cipta Media, 18). Level tinggi adalah posisi kaki menapak dengan tumit dalam bahasa Jawa disebut jinjit (Y.Sumandyo Hadi, 2014, Koreografi Bentuk-Teknik-Isi, Yogyakarta: Cipta Media, 18). Penggunaan level pada sebuah pertunjukan karya tari dijadikan sebagai variasi ruang, begitu juga pada bentuk penyajian Reyog Kendang Sanggar Sangtakasta yang mengolah level sebagai variasi ruang.

c. Pola Lantai

Pola lantai yang terdapat dalam Reyog Kendang ini menggunakan pola sejajar, zigzag, diagonal, simetris, dan melingkar.

\section{Aspek Waktu}

Waktu dalam pementasan dalam rangka Festival Gamelan Nusantara tahun 2017 Sanggar Sangtakasta sekitar tujuh menit. Penggunaan waktu dalam pementasan dapat dipengaruhi oleh cepat lambatnya Kendang 1 yang menjadi pemimpin Reyog Kendang. Waktu dipahami tidak hanya sebagai durasi 


\section{JOGED}

ISSN: $1858-3989$

saja, tetapi dalam melakukan gerak erat kaitannya dengan waktu. Seperti ritme dan tempo gerak, ritme dipahami sebagai perbedaan dari jarak waktu, perubahan atau pengulangan dengan jarak yang sama disebut ritme ajeg. Ritme dan tempo gerak memberi motivasi emosional, motivasi emosional yang dimaksud adalah dinamika gerak yang disatukan dengan iringan yang mampu membawa penari, pemusik, dan penonton mampu terbawa suasana dengan apa yang disajikan.

\section{Aspek Tenaga}

Salah satu motif yang menggunakan tenaga yang besar yaitu motif pengembaangan tangan dan pengembangan kaki. Tidak hanya memukul kendang sampai akhir, pada bagian awal tangan diolah dengan berbagai macam bentuk seperti ngukel dan ngeruji. Bagian akhir tarian juga membutuhkan tenaga walaupun gerak yang dilakukan satu motif yaitu drum band, namun dilakukan dengan berpindah tempat dengan beberapa pola lantai.

\section{Gerak Tari}

Nama motif dalam tarian ini sudah ada sejak dulu, adapun nama-nama motif Reyog Kendang sebagai berikut: Baris, Sundhangan, Andhul, Menthokan, Gejoh Bumi, Ngongak Sumur, Midak Kecik, Ling-lingan, Kejang,
Gembyangan, Drum band.

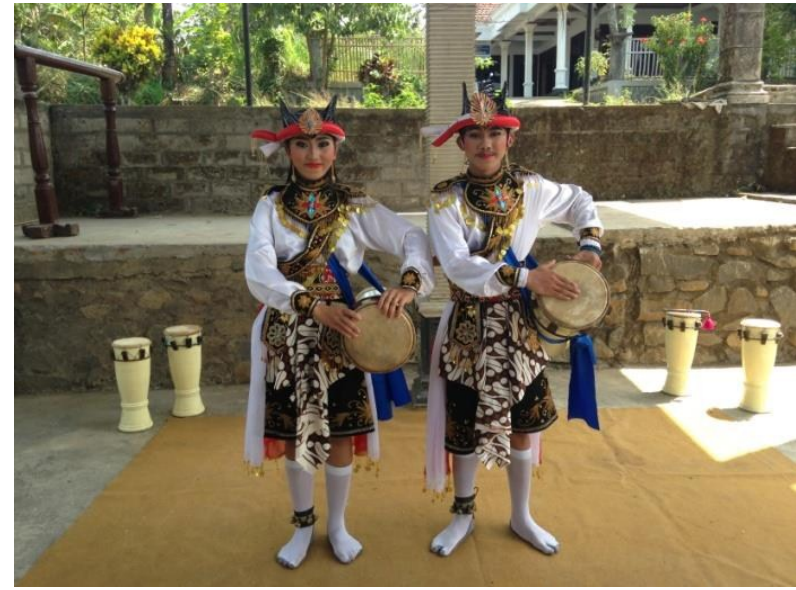

(Gambar 4. Kostum penari Reyog Kendang Sanggar Sangtakasta, dan sikap motif baris. 2013. Sanggar Sangtakasta. Dok: Yussi Ambar Sari).

\section{PENUTUP}

Reyog Kendang merupakan tarian khas Tulungagung yang bersumber pada cerita Dewi Kilisuci yang berisikan tentang lamaran. Tarian ini menggambarkan arakarakan prajurit ketika mengiringi Dewi Kilisuci menuju Gunung Kelud. Tema cerita yang dibawakan adalah keprajuritan, dan dibagi menjadi tiga bagian, yaitu bagian awal, tengah, dan akhir. Bagian awal menggambarkan arak-arakan prajurit ketika mengiringi Dewi Kilisuci menyaksikan pekerjaan Jathasura. Bagian tengah menggambarkan ketika Jathasura masuk ke dalam sumur dan dilempari batu oleh prajurit. Bagian akhir menunjukkan kegembiraan prajurit dan Dewi Kilisuci menuju Kerajaan Kediri.

Sajian tari Reyog Kendang Sanggar Sangtakasta dilihat dari bentuknya meliputi 
keutuhan gerak, variasi pola lantai, pengulangan gerak, transisi motif, arah hadap, dan level. Gerak dalam tarian ini menggambarkan beberapa gerak yang dilakukan oleh prajurit Dewi Kilisuci, yang divariasikan menjadi lebih ritmis dan dinamis. Pola lantai dalam tarian ini yaitu sejajar, zig-zag, diagonal, simetris, dan melingkar. Beberapa motif dalam tarian ini terdapat beberapa pengulangan gerak, misalnya pada bagian awal tarian terdapat motif sundhangan yang dilakukan $4 \times 8$ hitungan. Transisi menuju motif selanjutnya diberikan aba- aba oleh kendang 1 sebagai pemimpin tarian. Tarian ini memiliki bentuk gerak yang tegas, kuat, dan dinamis. Posisi mendhak mayuk, mendhak membungkuk, tolehan kepala, variasi gerakan tangan, serta kaki yang terbuka lebar dan nylekenthing, menjadi dominan dalam motif-motif gerak. Arah hadap dan level tinggi rendahnya dalam melakukan sebuah motif dimaksudkan supaya tarian terlihat menarik.

\section{Reyog Kendang Sanggar Sangtakasta} memiliki motif yang unik, yang tidak dimiliki oleh tarian lain. Motif pengembangan Sanggar Sangtakasta diantaranya pengembangan menthokan, pengembangan drum band, pengembangan kaki, pengembangan tangan, ongak-ongak, junjung tangan, ngongak sumur ngisor, dan perangan. Instrumen Reyog Kendang
Sanggar Sangtakasta yaitu kendang sebagai pemberi aba-aba masuk tarian, pergantian motif, serta mengakhiri tarian. Instrumen yang dipergunakan Sanggar Sangtakasta selain kendang yaitu saron demung, kenthongan, calung, gitar, siter, tamborin, drum, gong, kenong, suling, rinding, angklung, dan bass. Penyajian Reyog Kendang Sanggar Sangtakasta memiliki corak dan keunikan tersendiri, sehingga menawarkan daya tarik kepada penonton.

\section{DAFTAR SUMBER ACUAN}

A. Sumber Tertulis

Hadi, Y. Sumandyo. 2003. Aspek-aspek Dasar Koreografi Kelompok. Yogyakarta: eLKAPHI.

Hawkins, Alma M. 1990. Creating Through Dance. Terjemahan Y. Sumandiyo Hadi. Yogyakarta: ISI Yogyakarta.

Hidajat, Robby. 2011. Koreografi dan Kreatifitas Pengetahuan dan Petunjuk Praktikum Koreografi.Yogyakarta: Kendil Media Pustaka.

Hidajat, Robby. 2011. Koreografi dan Kreatifitas Pengetahuan dan Petunjuk Praktikum Koreografi.Yogyakarta: Kendil Media Pustaka.

Mugianto. dkk. 1996. Reyog Tulungagung Dalam Rangka Pendokumentasian, Pendiskripsian dan Pembuatan PedomanTari Khas Tulungagung. Tulungagung.

Smith, Jaqueline. 1985. Dance Composition" a Practical guide for teachers. London: A 
\& Black. Terjemahan Ben Suharto.

Komposisi Tari Sebuah Petunjuk Praktis

Bagi Guru. Yogyakarta: Ikalasti.

B. Narasumber

Bimo Wijayanto, 43 tahun, seorang generasi penerus penata tari Reyog Kendang.

Candra Boy Oka Utama, 23 tahun seorang penari dan penata tari Reyog Kendang di Tulungagung.

Endin Didik Handoko, 45 tahun, Ketua Sanggar Sangtakasta.

Sri Wahyuni, 55 tahun, Bagian Ekonomi Kreatif Dinas Pariwisata Tulungagung.

Untung Muljono, 59 tahun, seorang pencipta dan penata tari Reyog Kendang, serta penanggung jawab Sanggar Tari Kembang Sore. 